\title{
Supplementation of Growing Beef Heifers With Starch or Highly Digestible Fiber Supplements
}

\author{
Guillermo Scaglia ${ }^{1}$ \\ ${ }^{1}$ Louisiana State University Agricultural Center Iberia Research Station, Jeanerette, USA \\ Correspondence: Guillermo Scaglia, Louisiana State University Agricultural Center Iberia Research Station, 603 \\ LSU Bridge Road, Jeanerette, LA 70544-0466, USA. Tel: 337-276-5527. E-mail: gscaglia@agcenter.lsu.edu
}

Received: January 8, 2020

Accepted: February 9, $2020 \quad$ Online Published: March 15, 2020

doi:10.5539/jas.v12n4p14

URL: https://doi.org/10.5539/jas.v12n4p14

This research was financed by the USDA National Institute of Food and Agriculture, Hatch project 1004419.

\begin{abstract}
Producers are interested in cost-effective forage-based heifer development programs with supplemental feeding, if needed, of a single supplement (reducing the cost of mixed rations) so that it would meet their nutrient requirements. For three consecutive years, the effect of two levels of ground corn (GC) and soybean hulls pellets (SB), were evaluated on performance and grazing behavior of 90 replacement beef crossbred heifers $(\mathrm{BW}=$ $235 \pm 17 \mathrm{~kg}$; average of 10.8 months of age) grazing annual ryegrass (Lolium multiflorum; cv. 'Nelson') at low stocking rate. Treatments were: 1) no supplementation (CON); 2) $0.5 \% \mathrm{BW}$ of ground corn (GC05); 3) $0.5 \% \mathrm{BW}$ of soybean hull pellets (SB05); 4) 1\% BW of ground corn (GC1); and 5) 1\% BW of soybean hull pellets (SB1). Lower levels of supplements $(0.5 \% \mathrm{BW})$ allowed for greater $(P<0.05)$ ADG $(1.26$ and $1.21 \mathrm{~kg}$ for GC05 and SB05, respectively), production per hectare and lower age and BW at puberty. Ground corn or SB at $1 \%$ BW negatively affected $(P<0.05)$ growth $(0.88$ and $0.95 \mathrm{~kg}$, respectively), reproductive performance, number of steps, and grazing time (329 and 354 minutes, respectively) of heifers. Patch grazing time and bite rate were affected $(P<0.05)$ by grazing period due to changes in nutritive value of annual ryegrass and search for newly grown green leaves. Beef replacement heifers stocked at a low stocking rate with no supplementation may have a better development when compared to $1 \% \mathrm{BW}$ supplementation using $\mathrm{GC}$ or $\mathrm{SB}$ and similar to a $0.5 \% \mathrm{BW}$ supplementation level.
\end{abstract}

Keywords: annual ryegrass, beef heifers, ground corn, heifer development, soybean hulls, supplementation

\section{Introduction}

Producers are interested in cost-effective forage-based development programs, with supplemental feeding of a single supplement (reducing the cost of mixed rations) if needed, so that would meet the nutrient requirements of young replacement heifers. It has been demonstrated (Clark, Creighton, Patterson, \& Barrett, 2005; Stygar, Kristensen, \& Mukulska, 2014) that beef heifers should calve at $2 \mathrm{yr}$ of age to maximize profitability although their development is expensive and will notably affect the entire herd's productivity. In turn, and as demonstrated by Short and Bellows (1971) and Lesmeister, Burfening, and Blackwell (1973), all of those animals calving early in the season will have a greater chance to rebreed in the following breeding season (Burris \& Priode, 1958), had greater lifetime production reflected in greater weaning weights, and tended to calve earlier in subsequent years.

In order to increase the chance of beef heifers to get pregnant early in the breeding season they need to attain puberty as early as possible before it. Considerably data have shown that conception rates are very low on their first ovulation when compared with later estrous cycles. Byerley, Staigmiller, Berardinelli, and Short (1987) and Perry et al. (1991) demonstrated that the pregnancy rate of beef heifers increased an average of $20 \%$ at their $3^{\text {rd }}$ estrous compared to previous cycles. These data support the concept that earlier onset of puberty will impact conception rates throughout the animal's lifetime, increasing productivity but most importantly the economic and financial efficiency of the herd (Day \& Nogueira, 2013).

The proportion of mature BW which heifers must attain before undergoing puberty has been an issue of discussion for several decades and there is still some controversy. Despite these differences exist between European beef breeds and breed types (60\%), smaller percent (55\%) for dual purpose beef/dairy breeds, while 
Bos indicus cattle need the largest proportion of mature BW (65\%) to reach puberty (Larson, 2007). Traditionally the recommended target weights for beef heifers at puberty (pre-breeding) was 0.60 to 0.65 (Whittier, Lardy, \& Johnson, 2005; Engelken, 2008), and at first breeding, 0.65 to 0.70 (Whittier et al., 2005; Perry, 2012) of estimated mature weight. The rationale for having these target weights is that it will ensure that most if not all of the heifers are post-pubertal when the breeding season starts, can develop correctly during gestation diminishing the chance to have dystocia at calving and facilitates earlier restart of cyclicity for a successful second breeding. Funston, Martin, Larson, and Roberts (2012) suggested that the percent BW at breeding may be lowered to 0.50 to 0.57 of mature $\mathrm{BW}$, although in these instances, the proportion of heifers pubertal before the start of the breeding season and the pregnancy rate of heifers early in the breeding season might be smaller compared with those attained with greater BW (Perry, 2012; Gasser, 2013).

By-product feeds that have more than 75\% TDN and less than 30\% non-structural carbohydrates or NSC include soybean hulls, wheat middlings, corn gluten feed, beet pulp, citrus pulp, distillers' grains, and brewers' grains (Kunkle, Johns, Poore, \& Herd, 2000). The first three by-products have been available across much of the United States at reasonable prices and have been evaluated in several research trials during the last $20 \mathrm{yr}$. Soybean hulls, a by-product of soybean processing, are nearly balanced in CP (12 to $14 \%), \mathrm{Ca}(0.63 \%)$, and $\mathrm{P}(0.23 \%)$ for supplementing beef cattle (NASEM, 2016), palatable and have low risk of acidosis, consequently, this commodity feed is often fed without blending with other ingredients.

Type of energy concentrate (starch-based or fiber-based), level of it (as a \% of BW) and pasture allowance may have an effect on dry matter intake and ruminal environment. When forage allowance and forage intake were low, starchy concentrate had little effects on substitution rate (Meijs \& Hoekstra, 1984). High concentration of soluble sugars or starch tend to affect the rumen environment (decrease ruminal $\mathrm{pH}$ and increase concentration of volatile fatty acids and lactate). These effects varied by herbage composition (Galyean \& Goetsch, 1993; Dixon \& Stockdale, 1999). Several by-products, such as soybean hulls, contain less starch and more cell wall carbohydrates than the cereal-based concentrate. Their greater filling effects in the rumen could be counterbalanced by a favorable influence on ruminal fermentation (Jarrige et al., 1986).

The purpose of this work was to determine the effect of supplementation of beef heifers grazing annual ryegrass with soybean hulls and ground corn at two levels $(0.5$ and $1 \% \mathrm{BW})$ on performance, grazing behavior, and attainment of puberty.

\section{Materials and Methods}

The present study was conducted in three consecutive winters at the Louisiana State University Agricultural Center (LSU AgCenter) Iberia Research Station (IRS) located in Jeanerette, LA (29 ${ }^{\circ} 57^{\prime} 54^{\prime \prime}$ W latitude; 91 ${ }^{\circ} 42^{\prime} 54^{\prime \prime}$ $\mathrm{N}$ longitude; altitude $5.5 \mathrm{~m}$ ). The soil type is classified as Iberia silty clay loam with risk of flooding, although the experimental area had previously been shaped to improve drainage.

\subsection{Weather Data}

Monthly information on average air temperature $\left({ }^{\circ} \mathrm{C}\right)$ and rainfall $(\mathrm{mm})$ was obtained from a weather station located at the IRS approximately $320 \mathrm{~m}$ from the center of the experimental site. Monthly average weather data for the last $45 \mathrm{yr}$ (1970-2015) were obtained from https://www.ncdc.noaa.gov/cdo-web/ (select Jeanerette, LA).

\subsection{Treatments and Experimental Design}

Pasture size for all treatments was 1.62 ha. All pastures were planted with annual ryegrass (Lolium multiflorum; cv. 'Nelson') at a rate of $33 \mathrm{~kg} / \mathrm{ha}$ using a $4.5 \mathrm{~m}$ no-till planter (1590 John Deere ${ }^{\circledR}$, Moline, IL) in the month of September of 3 consecutive years $(2013,2014$, and 2015). There were five supplementation treatments consisting of: 1) no supplementation (CON); 2) $0.5 \% \mathrm{BW}$ of ground corn (GC05); 3) $0.5 \% \mathrm{BW}$ of soybean hull pellets (SB05); 4) 1\% BW of ground corn (GC1); and 5) 1\% BW of soybean hull pellets (SB1). Supplements were fed at 0730 every day and amount fed (average of the group BW) were adjusted every 15-d based on BW change. The treatments were arranged in a randomized block design with 3 replicates per treatment. Approximately one week before planting (September of every year) $1 \mathrm{~L} \mathrm{ha}^{-1}$ of 2-4D (2,4-dichlorophenoxyacetic acid 46.6\%) and $0.6 \mathrm{~L} \mathrm{ha}^{-1}$ Banvel (Dimethylamine salt of dicamba or 3,6-dichloro-0-anisic acid 48.2\%) were applied to eliminate existing unwanted (broadleaf) plant species. On the first yr soil samples were taken in all paddocks to determine any differences in $\mathrm{P}, \mathrm{K}$, and/or $\mathrm{pH}$. Based on soil test recommendations $1 \mathrm{t} \mathrm{ha}^{-1}$ of limestone was applied on surface to some paddocks ( 4 of the 15 paddocks) to correct for $\mathrm{pH}$ differences. Every yr, 145 units of $\mathrm{N} \mathrm{ha}^{-1}$ in the form of urea were applied. Nitrogen fertilization was split applied at 3 different times during the growing season. On average, the applications were on $\mathrm{d} 45,130$, and $181 \mathrm{~d}\left(56,56\right.$, and 33 units of $\mathrm{N} \mathrm{ha}^{-1}$, 
respectively) after planting. Average grazing starting date was approximately on d 101 after planting (at a height of approximately $21.3 \mathrm{~cm}$ ) and length of grazing season was $105 \mathrm{~d}$.

\subsection{Forage Measurements}

Forage mass was determined at the beginning of the trial $(\mathrm{d} 0)$ and every $14 \mathrm{~d}$ thereafter using the double sampling technique (Wilm, Costello, \& Klipple, 1944) with a similar plate meter and methodology as that described by Sanderson, Rotz, Fultz, \& Rayburn (2001) and Vendramini et al. (2006). Briefly, all paddocks were walked in zig-zag pattern by an observer who visually identified 10 sections that represent the variability observed across the paddocks. In these 10 sections, the area under the plate meter $\left(0.10 \mathrm{~m}^{2}\right)$ was sampled. Ten measurements of height $(\mathrm{cm})$ were determined within the area under the plate and then the plate meter was allowed to fall and plate meter reading $(\mathrm{cm})$ was recorded. Afterwards, the area under the plate was clipped to $2.54 \mathrm{~cm}$ using hand-clippers, avoiding soil contamination. Forage was placed in a paper bag, weighed and placed in a force air oven at $55{ }^{\circ} \mathrm{C}$ for $48 \mathrm{~h}$. After drying, the bag was weighed again for DM determination. These 10 data points generated were used to obtain the regression equation (between forage mass and forage height) that allowed the estimation of forage mass for each paddock. Fifty readings were obtained from each paddock using the plate meter and values recorded. These values were the input for the regression equation generated as indicated before. Forage height was estimated using a quadrat $\left(0.25 \mathrm{~m}^{2}\right)$ which was randomly placed 10 times in each paddock. Within it, 10 measurements of forage height $(\mathrm{cm})$ were recorded using a ruler. The average of these measurements represents the pasture height for the paddock at the time of sampling. Samples of forage for nutritive value analyses were hand-plucked from every paddock every $14 \mathrm{~d}$, walking the pasture in zig-zag pattern and taking a sample every 10 steps. Samples for nutritive value analyses were dried for DM determination in a force air oven at $55^{\circ} \mathrm{C}$ for $48 \mathrm{~h}$ (AOAC, 2000). Forage samples were ground to pass a $1 \mathrm{~mm}$ screen using a Wiley mill (Laboratory Mill model 4, Arthur H. Thomas Co. Philadelphia, PA, USA). Samples of forages were sent for analyses to a commercial laboratory (Dairy One Forage Laboratory, Ithaca, NY) and analyses accomplished using proximate analyses.

\subsection{Animal Management and Sampling}

The animal handling procedures used in this experiment were approved by the LSU AgCenter Animal Care and Use Committee. Beef heifers $(\mathrm{n}=90 ; \mathrm{BW}=235 \pm 17 \mathrm{~kg}$; average of 10.8 months of age $)$ with different proportions of Bos taurus $\times$ Bos indicus (not more than $1 / 3$ B. indicus) were continuously stocked at 3.7 heifers $\mathrm{ha}^{-1}$ or $870 \mathrm{~kg} \mathrm{BW} / \mathrm{ha}\left(6\right.$ heifers treatment replicate $\left.{ }^{-1}\right)$. Prior to weaning, heifers were vaccinated twice (August and September of every yr) with Bovishield Gold FP VL5 (Pfizer Animal Health, New York, NY), Clostridium 8-way w/Somnus (Bayer Vision; Intervet, Boxmeer, The Netherlands), Anthrax spore vaccine (Colorado Serum Co., Denver, CO), Pulmo Guard PHM-1 (Boehringer Ingelheim; Ridgefield, CT) and were dewormed (August only) with Valbazen (Albendazole, Pfizer Animal Health). After weaning (mid-October of each year) until approximately $2 \mathrm{wk}$ before the start of the grazing period, heifers were maintained on a diet of bermudagrass hay (ad libitum) and soybean hulls daily fed at 1\% BW. Every yr and $2 \mathrm{wk}(\mathrm{d}-14)$ before the start of the experiment, heifers were placed on annual ryegrass for acclimation. Heifers were weighed on $\mathrm{d} 0$ and every $15 \mathrm{~d}$ thereafter to determine ADG per 15-d period, total ADG for the entire grazing period, beef produced per unit of land, adjust the amount of supplement fed, and blood sampling for progesterone determination. Beef produced per unit of land was estimated by the difference between final and starting BW divided by the area (1.62 ha) of each paddock. Blood was collected via jugular venipuncture in 15-mL Vacutainer tubes (BD Inc., Franklin Lakes, NJ) for analysis of progesterone. After collection, blood remained at room temperature for an hour. After this time, it was placed at $4{ }^{\circ} \mathrm{Celsius}$ for $2 \mathrm{~h}$, and then serum separated using a centrifuge at $1000 \mathrm{~g}$ for $30 \mathrm{~min}$. Serum was stored at $-20^{\circ}$ Celsius for later analyses. A radioimmunoassay kit (MP Biomedical, Santa Ana, CA) was used for serum progesterone determination. Based on these data, the time of first estrous was the first day of 2 consecutive sampling dates with a serum progesterone concentration greater than $1 \mathrm{ng} / \mathrm{mL}$ or when the concentration was greater than $2 \mathrm{ng}$ of progesterone $/ \mathrm{mL}$ of serum. Two weeks before breeding, reproductive tract scores (transrectal ultrasonography) were determined using a scale of 1 to 5 ( $1=$ immature uterine horns and no palpable follicles or toned ovary; $5=$ uterine horns with a diameter of $3 \mathrm{~cm}$ or greater and follicles on the ovaries greater than $100 \mathrm{~mm}$, presence of corpus luteum, and toned ovary) following Pence et al. (1999).

On d 45 of the experimental period, heifers were dewormed with Ivomec Plus Injectable (Merial; Duluth, GA). Mineral mix that guaranteed $12 \% \mathrm{Ca}, 6 \% \mathrm{P}, 10 \% \mathrm{NaCl}, 2.50 \% \mathrm{Mg}, 0.75 \% \mathrm{~K}, 0.0043 \% \mathrm{Cu}, 0.00012 \% \mathrm{Se}$, $0.0067 \%$ Zn, 200,000 IU of Vitamin A (Lone Star 126, Lone Star Feeds; Corpus Christi, TX) and fresh water were always available. 


\subsection{Behavior Measurements}

Visual observations and behavior recordings use activity monitors were conducted following Scaglia and Boland (2014).

\subsubsection{Visual Observations}

These were conducted on three heifers per treatment replicate on three 3-d periods (period A, B, and C) starting on $\mathrm{d} 28,56$, and 90 of each grazing season. In each period, number of grazing patches (patches $\mathrm{min}^{-1}$ ) and bite rate (number of bites $\mathrm{min}^{-1}$ ) of the tester heifers was determined once per hour as long as there was enough visibility from 0700 to 1700 . The order in which each heifer (within period) was observed was pre-determined and was the same every time. In order to avoid affecting heifers' grazing behavior, a single observer using binoculars and a chronometer was positioned approximately $50 \mathrm{~m}$ from the animals to register the number of grazing patches and number of bites $\mathrm{min}^{-1}$. If the animal was not grazing, the activity (standing, walking, or lying) and whether the animal was ruminating were recorded.

\subsubsection{Use of Activity Monitors}

Every yr, grazing behavior recordings were conducted through the entire grazing season on one heifer per treatment replicate, each wearing an animal activity monitor. This monitor (IceTag ${ }^{\mathrm{TM}}$, version 2.004, IceRobotics, Midlothian, Scotland, UK) was attached to a Velcro ${ }^{\circledR}$ strap on the left rear leg just above the metatarsophalangeal joint. These units measured animal activity 8 times $\mathrm{s}^{-1}$ with an internal accelerometer. Percentage of time spent standing, active, lying, and number of steps taken by each heifer was recorded. Data were downloaded from on-board memory to a personal computer and analyzed by IceTagAnalyser ${ }^{\mathrm{TM}}$ software (version 2.009 , IceRobotics). Raw activity monitor data were transformed using the procedure of Aharoni et al. (2009) to partition out the amount of time spent standing still, grazing, and walking without grazing. In brief, the data were first summarized into 5-min intervals. If less than 10 steps were taken during that interval, the animal was considered to be standing still, if between 10 and 80 steps were taken the animal was considered to be grazing, and if more than 80 steps were taken, the animal was considered to be walking without grazing. Information obtained from each animal activity monitor was summarized by day $(24 \mathrm{~h})$ and averaged every $14 \mathrm{~d}$ (sampling period) within year. The same information was also summarized by TOD: 0700 to 1059 (AM), 1100 to 1459 (NOON), and 1500 to $1859 \mathrm{~h}(\mathrm{PM})$.

\subsection{Statistical Analyses}

The experiment was a completely randomized design with 3 replicates. Data were analyzed with PROC Mixed of SAS (version 9.4, SAS Inc., Cary, NC). Treatment and period (or sampling date) were the fixed effects and year the random effect. Forage mass, height, and nutritive value were analyzed for treatment, sampling date and their interaction. Partial ADG (per period), total ADG (d 0 to 105) and beef production (gain) per hectare were analyzed for treatment, period and their interaction. Sampling date (for forage variables) and period (for ADG) were the repeated measures. In all cases, paddock was the experimental unit.

The repeated measure was day for all behavior data variables and analyzed using the MIXED procedure and the compound symmetry (cs) covariance structure. The model for pedometer recorder data (grazing, standing, and lying time, and number of steps) included treatment, sampling period, and treatment $\times$ sampling period interaction. The repeated measure was experimental period and the experimental unit was the paddock within sampling period. Paddock (within sampling period) was considered a random effect. Least squares means are reported for all variables with means separated by Tukey's adjustment. The GLIMMIX procedure was used to analyze the percentage of heifers cycling. Pasture was the experimental unit while animal (heifer) within a pasture served as the sampling unit. A significance level of $\alpha \leq 0.05$ was set for all analyses.

\section{Results}

Weather conditions during the three calendar years of the experiment is depicted in Table 1. During the experimental period (January-April of each year), Year 1 was the coldest, even colder than the $45 \mathrm{yr}$ average. Year 3 was characterized by heavy rainfall especially in November and during January and March. April in Year 2 was very wet with more than twice the rainfall when compared to Year 1, 3, and the historic average. There was no negative effect of weather conditions on annual ryegrass growth or animal performance; however, during times of excessive rainfall (Year 3) it was challenging to avoid muddy conditions in supplementation areas. 
Table 1. Weather data (monthly averages for maximum and minimum temperatures and total rainfall) for the grazing seasons 2013-2014 (Year 1), 2014-2015 (Year 2), and 2015-2016 (Year 3) obtained at the Iberia Research Station and historical data for the previous 45 years

\begin{tabular}{|c|c|c|c|c|c|c|c|c|c|c|c|c|}
\hline & \multicolumn{3}{|c|}{ Year 1} & \multicolumn{3}{|c|}{ Year 2} & \multicolumn{3}{|c|}{ Year 3} & \multicolumn{3}{|c|}{ HISTORIC $^{1}$} \\
\hline & $\operatorname{Max}^{2}$ & $\operatorname{Min}^{3}$ & Rain $^{4}$ & Max & Min & Rain & Max & Min & Rain & Max & Min & Rain \\
\hline $\mathrm{J}^{5}$ & 32.1 & 22.6 & 213.3 & 31.2 & 22.2 & 164.2 & 31.4 & 22.4 & 267.3 & 31.2 & 21.2 & 208.8 \\
\hline $\mathrm{J}$ & 31.5 & 22.4 & 198.9 & 31.5 & 21.9 & 280.5 & 33.6 & 23.6 & 44.4 & 32.6 & 22.3 & 171.3 \\
\hline A & 32.3 & 22.4 & 121.2 & 31.9 & 22.6 & 270.2 & 33.2 & 22.1 & 145.2 & 32.1 & 22.5 & 172.1 \\
\hline $\mathrm{S}$ & 31.6 & 20.9 & 122.9 & 30.5 & 21.0 & 73.9 & 30.4 & 20.5 & 130.2 & 30.8 & 19.2 & 162.9 \\
\hline $\mathrm{O}$ & 26.6 & 15.5 & 126.4 & 27.8 & 14.6 & 33.0 & 27.6 & 14.9 & 151.7 & 26.5 & 14.9 & 129.1 \\
\hline $\mathrm{N}$ & 19.8 & 8.2 & 96.7 & 18.9 & 6.0 & 41.9 & 22.9 & 13.3 & 346.6 & 22.1 & 10.2 & 100.4 \\
\hline $\mathrm{D}$ & 16.0 & 5.3 & 85.0 & 19.2 & 8.2 & 97.0 & 21.0 & 11.2 & 108.6 & 17.9 & 6.1 & 128.5 \\
\hline $\mathrm{J}$ & 13.2 & -0.1 & 74.5 & 14.9 & 3.8 & 84.4 & 15.4 & 4.6 & 162.8 & 16.0 & 5.8 & 124.8 \\
\hline $\mathrm{F}$ & 16.9 & 5.8 & 117.3 & 15.6 & 3.5 & 57.7 & 19.3 & 6.8 & 100.3 & 18.2 & 7.0 & 111.8 \\
\hline $\mathrm{M}$ & 19.3 & 7.7 & 47.8 & 22.6 & 11.8 & 100.2 & 23.0 & 13.1 & 164.6 & 21.6 & 10.1 & 99.9 \\
\hline A & 24.5 & 13.9 & 126.7 & 26.4 & 17.1 & 279.3 & 25.8 & 15.9 & 131.9 & 25.1 & 14.4 & 102.2 \\
\hline M & 27.6 & 16.8 & 120.9 & 29.3 & 19.7 & 214.3 & 28.1 & 18.6 & 260.3 & 29.4 & 18.5 & 110.8 \\
\hline
\end{tabular}

Note. ${ }^{1}$ HISTORIC: Historic weather data (1970-2015);

${ }^{2}$ Max: Average maximum monthly temperatures, Celsius;

${ }^{3}$ Min: Average minimum monthly temperatures, Celsius;

${ }^{4}$ Rain: Monthly rainfall, $\mathrm{mm}$;

${ }^{5}$ Months of the year, from J (June) to M (May) of the following year.

Forage mass and height did not limit animal performance throughout the experimental period (Table 2); however, there was a treatment effect for forage mass $(P<0.04)$ and height $(P=0.03)$. Ground corn $(\mathrm{GC} 1)$ had the greatest forage mass and height while $\mathrm{CON}$ the smallest. Forage nutritive value parameters were best for $\mathrm{CON}$ : greatest $\mathrm{CP}$ concentration and lowest NDF and ADF concentrations. Greatest levels of supplementation (1\%) had annual ryegrass with lower $\mathrm{CP}$ and greatest NDF and ADF concentration. Regardless of these values, TDN and IVTD were not different between treatments $(P>0.05)$.

Table 2. Effect of treatment (TRT) and sampling day (DAY) on forage mass ( $\mathrm{kg} / \mathrm{ha})$, height $(\mathrm{cm})$ and nutritive value parameters $(\% \mathrm{DM})$ of annual ryegrass

\begin{tabular}{|c|c|c|c|c|c|c|c|c|c|}
\hline \multirow{2}{*}{ Item } & \multicolumn{5}{|c|}{ Treatment, TRT $^{1}$} & \multirow{2}{*}{ SEM } & \multicolumn{3}{|c|}{$P$ values } \\
\hline & $\mathrm{CON}$ & GC05 & SB05 & $\mathrm{GC1}$ & SB1 & & TRT & DAY & TRT*DAY \\
\hline Forage mass, $\mathrm{kg} / \mathrm{ha}$ & $1804^{\mathrm{b}}$ & $2305^{\mathrm{ab}}$ & $2256^{\mathrm{ab}}$ & $3049^{a}$ & $2979^{\mathrm{a}}$ & 510 & 0.04 & 0.06 & 0.07 \\
\hline Forage height, $\mathrm{cm}$ & $19.5^{\mathrm{b}}$ & $21.0^{\mathrm{ab}}$ & $23.9^{\mathrm{ab}}$ & $30.1^{\mathrm{a}}$ & $28.9^{\mathrm{ab}}$ & 5.3 & 0.03 & 0.05 & 0.19 \\
\hline \multicolumn{10}{|c|}{ Nutritive value, \% DM } \\
\hline $\mathrm{CP}$ & $17.8^{\mathrm{a}}$ & $16.8^{\mathrm{a}}$ & $18.9^{\mathrm{a}}$ & $13.7^{\mathrm{b}}$ & $14.2^{\mathrm{ab}}$ & 1.7 & 0.01 & 0.33 & 0.82 \\
\hline NDF & $46.5^{b}$ & $47.6^{\mathrm{ab}}$ & $46.9^{b}$ & $52.1^{\mathrm{a}}$ & $51.7^{\mathrm{a}}$ & 2.2 & 0.04 & 0.21 & 0.69 \\
\hline $\mathrm{ADF}$ & $27.9^{b}$ & $30.7^{\mathrm{ab}}$ & $32.7^{\mathrm{ab}}$ & $35.4^{\mathrm{a}}$ & $33.1^{\mathrm{a}}$ & 2.4 & 0.04 & 0.94 & 0.17 \\
\hline TDN & 69 & 70 & 71 & 63 & 64 & 4 & 0.08 & 0.57 & 0.39 \\
\hline IVTD & 73 & 71 & 72 & 69 & 70 & 2.5 & 0.07 & 0.62 & 0.61 \\
\hline
\end{tabular}

Note. ${ }^{1}$ Treatments: $\mathrm{CON}=$ Control, no supplement; GC05 $=$ Ground corn at $0.5 \%$ BW; SB05 $=$ Soybean hulls pellets at $0.5 \% \mathrm{BW} ; \mathrm{GC1}=$ Ground corn at $1 \% \mathrm{BW}$; $\mathrm{SB} 1=$ Soybean hulls pellets at $1 \% \mathrm{BW}$.

Average daily gains and production per ha (Table 3) was maximized with $0.5 \% \mathrm{BW}$ of supplement; however, GC05 and SB05 were not different $(P>0.05)$ to CON. Greater levels of supplement reduced production per animal and unit of land when compared to $0.5 \% \mathrm{BW}$. Similarly, $\mathrm{CON}$ was not different $(P>0.05)$ to $\mathrm{GC} 1$ and SB1. 
Table 3. Effect of treatment (TRT) and sampling period (PER) on ADG ( $\mathrm{kg}$ ) and beef produced (kg/ha) by beef heifers grazing annual ryegrass and supplemented with different amounts of ground corn (GC) or soybean hulls (SB)

\begin{tabular}{|c|c|c|c|c|c|c|c|c|c|}
\hline \multirow{2}{*}{ Item } & \multicolumn{5}{|c|}{ Treatment, TRT $^{1}$} & \multirow{2}{*}{ SEM } & \multicolumn{3}{|c|}{$P$ values } \\
\hline & $\mathrm{CON}$ & GC05 & SB05 & $\mathrm{GC} 1$ & SB1 & & TRT & PER & TRT*PER \\
\hline ADG, $\mathrm{kg}$ & $1.12^{\mathrm{ab}}$ & $1.26^{\mathrm{a}}$ & $1.21^{\mathrm{ab}}$ & $0.88^{\mathrm{b}}$ & $0.95^{\mathrm{ab}}$ & 0.17 & 0.04 & 0.03 & 0.11 \\
\hline Beef production, $\mathrm{kg} / \mathrm{ha}$ & $435^{\mathrm{ab}}$ & $489^{\mathrm{a}}$ & $470^{\mathrm{a}}$ & $342^{\mathrm{b}}$ & $370^{\mathrm{b}}$ & 54.3 & 0.03 & 0.05 & 0.19 \\
\hline
\end{tabular}

Note. ${ }^{1}$ Treatments: $\mathrm{CON}=$ Control, no supplement; GC05 = Ground corn at $0.5 \% \mathrm{BW}$; SB05 = Soybean hulls pellets at $0.5 \% \mathrm{BW} ; \mathrm{GC1}=$ Ground corn at $1 \% \mathrm{BW} ; \mathrm{SB} 1=$ Soybean hulls pellets at $1 \% \mathrm{BW}$.

Heifers in CON had greatest number of steps and grazing minutes $(P<0.05)$ when compared to GC1 and SB1, while GC05 and SB05 were intermediate (Table 4). No significant differences were observed for the other grazing behavior variables.

Table 4. Effect of treatment (TRT) and sampling period (PER) on daily number of steps taken, walking time $(\mathrm{min})$, lying time $(\mathrm{min})$, and grazing time $(\mathrm{min})$ by beef heifers grazing annual ryegrass and supplemented with different amounts of ground corn (GC) or soybean hulls (SB)

\begin{tabular}{|c|c|c|c|c|c|c|c|c|c|}
\hline \multirow{2}{*}{ Item } & \multicolumn{5}{|c|}{ Treatment, TRT $^{1}$} & \multirow{2}{*}{ SEM } & \multicolumn{3}{|c|}{$P$ values } \\
\hline & $\mathrm{CON}$ & GC05 & SB05 & GC1 & SB1 & & TRT & PER & TRT*PER \\
\hline Number of steps & $3924^{\mathrm{a}}$ & $3654^{\mathrm{ab}}$ & $3811^{\mathrm{a}}$ & $2699^{\mathrm{c}}$ & $2991^{b c}$ & 482 & 0.01 & 0.81 & 0.31 \\
\hline Walking, min & 34 & 36 & 37 & 28 & 29 & 7.5 & 0.21 & 0.61 & 0.88 \\
\hline Lying, min & 705 & 736 & 758 & 781 & 775 & 41 & 0.06 & 0.87 & 0.37 \\
\hline Standing, min & 201 & 211 & 230 & 251 & 242 & 21 & 0.07 & 0.21 & 0.09 \\
\hline Grazing, min & $442^{\mathrm{a}}$ & $401^{\mathrm{ab}}$ & $381^{\mathrm{ab}}$ & $329^{\mathrm{c}}$ & $354^{\mathrm{bc}}$ & 31 & 0.02 & 0.08 & 0.07 \\
\hline
\end{tabular}

Note. ${ }^{1}$ Treatments: $\mathrm{CON}=$ Control, no supplement; GC05 = Ground corn at $0.5 \% \mathrm{BW}$; SB05 = Soybean hulls pellets at $0.5 \% \mathrm{BW} ; \mathrm{GC} 1=$ Ground corn at $1 \% \mathrm{BW}$; $\mathrm{SB} 1=$ Soybean hulls pellets at $1 \% \mathrm{BW}$.

Number of steps were greater $(P<0.05)$ in the AM and PM; however, there was an interaction $(P=0.02)$ for grazing time (Table 5). Heifers in CON grazed longer than GC1 and SB1 supplemented treatments in the AM (156 min vs. 64 and $75 \mathrm{~min}$; respectively) while supplemented heifers (CG1 and SB1) did so in the PM (310 and 338 min vs. $254 \mathrm{~min}$; respectively). Lying time was greater $(P<0.05)$ in the AM and NOON. No differences due to treatment were observed. While observing grazing activity (Table 6), heifers spent more time in period A grazing a single patch $(P=0.02)$ than in periods $\mathrm{B}$ and $\mathrm{C}$. There was a significant interaction $(P=0.04)$ for bite rate. Heifers in CON had greater bite rate compared to CG1 and SB1 (71 vs. 56 and 59 bites per minute) in period A and smaller in period C (50 vs. 63 and 60, respectively).

Table 5. Effect of treatment (TRT) and time of the day (TOD; AM, NOON, and PM) on daily number of steps taken, walking time $(\mathrm{min})$, lying time $(\mathrm{min})$, and grazing time $(\mathrm{min})$ of beef heifers grazing annual ryegrass alone (RG) and supplemented with different amounts of ground corn (GC) or soybean hulls (SB)

\begin{tabular}{|c|c|c|c|c|c|c|c|}
\hline \multirow{2}{*}{ Item } & \multicolumn{3}{|c|}{ Time of the day, TOD } & \multirow{2}{*}{ SEM } & \multicolumn{3}{|c|}{$P$ values } \\
\hline & AM & NOON & PM & & TRT & TOD & TRT*TOD \\
\hline Number of steps & $1107^{\mathrm{a}}$ & $212^{\mathrm{b}}$ & $1597^{\mathrm{a}}$ & 359 & 0.09 & 0.001 & 0.06 \\
\hline Walking, min & $11^{\mathrm{ab}}$ & $5^{\mathrm{b}}$ & $18^{\mathrm{a}}$ & 5 & 0.42 & 0.01 & 0.66 \\
\hline Lying, min & $33^{\mathrm{a}}$ & $78^{\mathrm{a}}$ & $8^{b}$ & 27 & 0.13 & 0.04 & 0.08 \\
\hline Grazing, min & $103^{\mathrm{b}}$ & $71^{\mathrm{b}}$ & $267^{\mathrm{a}}$ & 31.7 & 0.12 & 0.01 & 0.02 \\
\hline
\end{tabular}


Table 6. Time spent grazing on a patch $\left(\mathrm{s}^{-1}\right)$ and bite rate (bites $\min ^{-1}$ ) during three periods of visual observation (A-C) by beef heifers grazing annual ryegrass and supplemented with different amounts of ground corn (GC) or soybean hulls pellets (SB)

\begin{tabular}{|c|c|c|c|c|c|c|c|}
\hline \multirow{2}{*}{ Item } & \multicolumn{3}{|c|}{ Period, PER } & \multirow{2}{*}{ SEM } & \multicolumn{3}{|c|}{$P$ values } \\
\hline & $\mathrm{A}$ & $\mathrm{B}$ & $\mathrm{C}$ & & TRT & PER & TRT*PER \\
\hline Patch grazing, $\mathrm{s}^{-1}$ & $26.0^{\mathrm{a}}$ & $18.0^{\mathrm{b}}$ & $18.5^{\mathrm{b}}$ & 3.8 & 0.11 & 0.02 & 0.73 \\
\hline Bite rate, bites $\min ^{-1}$ & $69^{\mathrm{a}}$ & $52^{b}$ & $55^{b}$ & 6 & 0.07 & 0.04 & 0.04 \\
\hline
\end{tabular}

Body weight at puberty was different (Table 7) between GC05 and GC1 with the heifers in all other treatments not differing from the GC treatments. Age at puberty was greater $(P<0.05)$ for CON and SB1. Heifers in GC05 and SB05 had the lowest age at puberty.

Table 7. Effect of treatment (TRT) on reproductive performance of beef heifers grazing annual ryegrass alone (RG) and supplemented with different amounts of ground corn (GC) or soybean hulls (SB)

\begin{tabular}{lllllll}
\hline \multirow{2}{*}{ Item } & \multicolumn{5}{c}{ Treatment, TRT $^{1}$} & \multirow{2}{*}{ SEM } \\
\cline { 2 - 6 } & CON & GC05 & SB05 & GC1 & SB1 & \\
\hline Reproductive tract score & 3.4 & 3.6 & 3.5 & 3.4 & 3.4 & 0.33 \\
Heifers cycling, \% & 54 & 59 & 60 & 58 & 59 & 3.1 \\
BW at puberty, kg & $321^{\mathrm{ab}}$ & $318^{\mathrm{b}}$ & $326^{\mathrm{ab}}$ & $335^{\mathrm{a}}$ & $327^{\mathrm{ab}}$ & 7.5 \\
Age at puberty, days & $372^{\mathrm{b}}$ & $369^{\mathrm{b}}$ & $371^{\mathrm{b}}$ & $385^{\mathrm{ab}}$ & $390^{\mathrm{a}}$ & 9.2 \\
\hline
\end{tabular}

Note. ${ }^{1}$ Treatments: $\mathrm{CON}=$ Control, no supplement; GC05 = Ground corn at $0.5 \% \mathrm{BW}$; SB05 = Soybean hulls pellets at $0.5 \% \mathrm{BW}$; GC1 = Ground corn at 1\% BW; SB1 = Soybean hulls pellets at 1\% BW.

\section{Discussion}

Stocking rate is defined as the relationship between the number of animals and the grazing management unit utilized over a specified time period (Forage and Grazing Terminology Committee, 1991). To correctly defined an appropriate stocking rate, there is a need for knowledge on forage production and grazing pressure (Scaglia, 2019). This will help improve production efficiency and economic returns. Replacement heifers represent the next generation of cows in a herd and ideally each year's cohort of heifers should be genetically superior for commercially important traits compared with their predecessors. Significant costs are incurred during the rearing of replacement heifers and it is imperative that they become pregnant early in their first breeding season, encounter minimal dystocia, are successfully rebred to calve again within 365 days and ultimately have long (more than 8 lactations) and productive lives within the herd (Diskin \& Kenny, 2014). Heifers must be placed on a high plane of nutrition to achieve puberty soon enough so that they may conceive at 14 to 15 mo of age (Short \& Bellows, 1971). Energy intake is the primary nutritional consideration for reproductive development of beef heifers (Mass, 1987). However, the expenses associated with energy supplementation can significantly increase production costs and become unattractive to cow-calf producers. Previously (Scaglia, 2019), evaluated the effect of supplementation at high stocking rates. This management practice did not improve ADG over the same stocking rate with no supplementation although it allows for greater beef production per hectare. When defining the present experiment, and to complement previous work, the decision was to use a stocking rate that would not interact with level or type of supplement under evaluation, hence we used one that is lower than the stocking rate normally use of $990 \mathrm{~kg} \mathrm{BW} \mathrm{ha}^{-1}$ (Scaglia et al., 2009) at the same location. Forage mass, height, and nutritive value (Table 2) were never limitations to maximize DMI (Paterson, Belyea, Bowman, Kerley, \& Williams, 1994) and were similar to those previously reported under similar management and environmental conditions (Hafley, 1996; Scaglia, Gillespie, Boland, \& Wyatt, 2009a; Scaglia, Boland, \& Wyatt, 2009b; Scaglia, 2019). Even though, as expected, CON would have less DM available, values throughout the experimental period were above those suggested as limiting for performance $(800 \mathrm{~kg} \mathrm{DM} / \mathrm{ha})$ by Paterson et al. (1994) and similar to those reported for low stocking rate by Scaglia (2019). Forage mass and height of pastures in GC1 and SB1 are greater than those reported by Scaglia (2019) when supplemented with the same level and type of supplements but at a greater stocking rate. In the present experiment, there was a clear substitution of annual ryegrass with supplement, despite the lower stocking rate.

Horn and McCollum (1987) reviewed energy supplementation of grazing ruminants and concluded that concentrates can be fed up to $0.5 \%$ of BW without causing large decreases in forage intake. Bowman \& Sanson 
(1996) reviewed literature on types of energy supplements for grazing ruminants and concluded that supplementing grain-based supplements up to $0.25 \% \mathrm{BW}$ had minimal effects on forage utilization but above $0.25 \%$ BW negative effects were much larger.

Several trials evaluated similar quantities of corn and soybean hulls supplements on gains of growing cattle, and reported gains were similar for levels ranging from 0.4 to 1.0\% BW (McDonnell et al., 1982; Anderson, Merrill, \& Klopfenstein, 1988a; Anderson, Merrill, McDonnell, \& Klopfenstein, 1988b; Brown \& Weigel, 1993). Studies comparing corn and SB supplementation effects on forage intake and digestibility suggest advantages for SB, especially when fed at levels above $0.5 \% \mathrm{BW}$. The potential for use of these byproduct feeds in supplementing growing cattle on high nutritive value pastures is particularly good because of the rapid rate of ruminal degradation of wheat forage (Zorrilla-Rios, Horn, Ford, McNew, \& Poling, 1985) and the relatively low ruminal pH (Andersen \& Horn, 1987). In the present experiment, greater levels of GC or SB (1\% BW) did not have a positive effect of animal performance (Table 3), with GC1 presenting the smallest ADG (0.88 $\mathrm{kg})$ and productivity $(342 \mathrm{~kg} / \mathrm{ha})$. On the other hand, heifers supplemented with $0.5 \% \mathrm{BW}$ of GC had the greatest $(P<$ 0.05) production. Similarly, Scaglia (2019) found that growing animals at a low stocking rates may guarantee greater performance when compared to those at greater stocking rate with or without supplementation.

Grazing time is usually divided into several well-defined periods of activity during the day and night, and depending on swards and environmental conditions, the number of periods may differ, although there are two clearly defined: at early hours in the morning and late afternoon into evening (Hodgson, Clark, \& Mitchell, 1994). Scaglia et al. (2009) indicated that grazing frequency and grazing time can be affected by the external environment (i.e., rainfall and temperature) and also by behavioral adaptations (i.e., supplementation). Sward surface height is a major determinant of bite characteristics (Black \& Kenney, 1984; Burlison, Hodgson, \& Illius, 1991) including bite mass (g/bite) and intake rate (bites/min). Supplementation can cause shifts in daytime grazing behavior patterns. Adams (1985) postulated that disruption of normal grazing activity resulting from supplementation regimens could adversely affect forage intake and animal performance. Heifers supplemented with greater amount of GC had their grazing behavior negatively affected (Table 4) due to reduction in number of steps $(P=0.01)$, and less grazing time $(P=0.02)$. Even though not measured in this present experiment, we hypothesized that excess supplement may have caused a reduction in ruminal $\mathrm{pH}$ affecting fiber digestibility, dry matter intake, and ultimately performance (Table 3). Since grains are usually more digestible than forages, a linear increase in digestibility of the diets might be expected as the proportion of grain in the diet is increased. However, digestibility in the entire gastrointestinal tract of mixed grain-forage diets often increased less than should occur with forage and grain when they are fed separately, due to the reduced digestion of the fibrous components of the forage (Van der Linden, Van Gylswyk, \& Schwartz 1984; Kennedy \& Bunting, 1992; Grigsby, Kerley, Paterson, \& Weigel, 1993). Ruminants can partially compensate for a reduced rate of fiber digestion in the rumen by increasing retention time of fibrous residues in this compartment, but when this occurs forage intake usually decreases (Dixon \& Stockdale, 1999). The $\mathrm{pH}$ of the ruminal fluid is reduced by digestion of grain and this appears to be an aspect of growth of cellulolytic bacteria difficult to manipulate (Russell \& Wilson, 1996). The rate of digestion of NDF is near the maximum at ruminal fluid $\mathrm{pH}$ of 6.2-7.0 and drops precipitously in a nearly linear fashion to zero digestion rate at $\mathrm{pH}$ 5.5-5.7 (Pitt et al., 1996; NASEM, 2016). The NDF digestibility reduction caused by addition of starch to the diet could be attributed to a lower ruminal $\mathrm{pH}$ or directly to presence of starch in the rumen. The abundance of cellulolytic organisms relative to fiber substrate that is susceptible to colonization ensures some level of fiber digestion even at low $\mathrm{pH}$. However, if there are not periods during the day in which ruminal $\mathrm{pH}$ approaches or exceeds $\mathrm{pH} 6$, and growth of the cellulolytic bacteria can proceed, the population of cellulolytic organisms will diminish. In that case, growth cannot keep pace with the dilution rate, and wash-out of the organisms will occur (Satter, Jung, van Vuuren, \& Engels, 1999). In addition to the negative effect of the high level of supplementation (GC1 and SB1) on the rumen environment there was also an effect on the behavioral adaptation to supplementation. Number of steps and walking time were greater $(P=0.001$ and 0.01 , respectively) in the AM and PM (Table 5); however, grazing time was greater in the PM $(P=0.01)$. This is explained buy the reduced time spent grazing by supplemented heifers during the AM hours while dedicating the greater bout of grazing time in the PM. Similar results were obtained by Scaglia et al. (2009); in that case steers supplemented in the AM spent most of their daily time grazing in the PM as a result of receiving the supplement in the AM.

Grazing forms a mosaic of patches of varying size in a sward, increasing the difference between preferred and nonpreferred species (Mott, 1985) or previously defoliated vs. non-defoliated plants so that once the mosaic is formed, it tends to be maintained (Willms, Dormaar, \& Schaalje, 1988), avoiding patches with senescent materials (Mott, 1985; Ganskopp, Angell, \& Rose, 1993). In the present experiment, the reduced time spent $(P=$ 
0.02) on a patch in period $\mathrm{B}$ and $\mathrm{C}$ (Table 6) might be associated with reduced annual ryegrass nutritive value and the fact that cattle will search for the new regrowth or for more tender plant components. In period A annual ryegrass was more succulent, with greater nutritive value, mass, and height, so it did not negatively impact bite placement. Bite rate declines as green leaves are removed as grazing season advances and the trade-off of looking for greener material and/or more succulent affected it and time spent on a patch.

Reproductive function of beef heifers is highly associated with nutritional status, growth rates, and circulating concentrations hormones and metabolites associated with energy metabolism (Roberts, Nugent, Klindt, \& Jenkins 1997; Wettemann \& Bossis, 2000; Diskin, Mackey, Roche, \& Sreenan, 2003). In the present experiment, greater levels of supplementation $(1 \% \mathrm{BW})$ did not improve any of the reproductive performance indicators evaluated (Table 7) when compared to non-supplemented heifers. This is related to differences observed in ADG and grazing behavior. A smaller amount $(0.5 \% \mathrm{BW})$ of energy supplement $(\mathrm{GC}$ or $\mathrm{SB})$ reduced the $\mathrm{BW}$ and age at puberty and improved efficiency of supplementation. A producer can improve the response to energy supplements by feeding a lower level $(0.5 \% \mathrm{BW})$ when a good supply of forage is available instead of using higher levels and hence compromising the economic feasibility of developing heifers.

\section{Acknowledgements}

Thanks to the LSU AgCenter Iberia Research Station personnel for the care of experimental animals.

\section{References}

Adams, D. C. (1985). Effect of time of supplementation on performance, forage intake and grazing behavior of yearling beef steers grazing Russian wild ryegrass in the fall. Journal of Animal Science, 61, 1037. https://doi.org/10.2527/jas1985.6151037x

Aharoni, Y., Henkin, Z., Ezra, A., Dolev, A., Shabtay, A., Orlov, A., ... Brosh, A. (2009). Grazing behavior and energy costs of activity: A comparison between two types of cattle. Journal of Animal Science, 87, 2719-2731. https://doi.org/10.2527/jas.2008-1505

Andersen, M. A., \& Horn, G. W. (1987). Effect of lasalocid on weight gains, ruminal fermentation and forage intake of stocker cattle grazing winter wheat pasture. Journal of Animal Science, 65, 865-871. https://doi.org/10.2527/jas1987.654865x

Anderson, S. J., Merrill, J. K., \& Klopfenstein, T. J. (1988a). Soybean hulls as an energy supplement for the grazing ruminant. Journal of Animal Science, 66, 2959-2964. https://doi.org/10.2527/jas1988.66112959x

Anderson, S. J., Merrill, J. K., McDonnell, M. L., \& Klopfenstein, T. J. (1988b). Digestibility and utilization of mechanically processed soybean hulls by lambs and steers. Journal of Animal Science, 66, 2965-2976. https://doi.org/10.2527/jas1988.66112965x

AOAC. (2000). Official Methods of Analysis (17th ed.). AOAC Intl. Gaithersburg, MD, USA.

Black, J. L., \& Kenney, P. A. (1984). Factors affecting diet selection by sheep. II. Effects of height and density of pasture. Australian Journal of Agricultural Research, 35, 565-578. https://doi.org/10.1071/AR9840565

Bowman, J. G. P., \& Sanson, D. W. (1996). Starch- or fiber-based energy supplements for grazing ruminants. In M. B. Judkins \& F. T. McCollum III (Eds.), Proc. 3rd Grazing Livestock Nutrition Conf., Proc. West. Sect. Am. Soc. Anim. Sci. (Suppl. 1, pp. 118-135).

Brown, W. F., \& Weigel, J. (1993). Utilization of soybean hulls in supplemental programs for beef cattle. Proc. 4th Annu. Florida Ruminant Nutr. Symp. (pp. 76-89). Univ. of Florida, Gainesville.

Burlison, A. J., Hodgson, J., \& Illius, A. W. (1991). Sward canopy structure and the bite dimensions and bite weight of grazing sheep. Grass and Forage Science, 46, 29-38. https://oi.org/10.1111/j.1365-2494.1991. tb02205.x

Burris, M. J., \& Priode, B. M. (1958). Effect of calving date on subsequent calving performance. Journal of Animal Science, 17, 527-533. https://doi.org/10.2527/jas1958.173527x

Byerley, D. J., Staigmiller, R. B., Berardinelli, J. G., \& Short, R. E. (1987). Pregnancy rates of beef heifers bred either on puberal or third estrus. Journal of Animal Science, 65, 645-650. https://doi.org/10.2527/ jas1987.653645x

Clark, R. T., Creighton, K. W., Patterson, H. H., \& Barrett, T. N. (2005). Symposium Paper: Economic and tax implications for managing beef replacement heifers. Professional Animal Scientist, 21, 164-173. https://doi.org/10.15232/S1080-7446(15)31198-0 
Day, M. L., \& Nogueira, G. P. (2013). Management of age at puberty in beef heifers to optimize efficiency of beef production. Animal Frontiers, 3(4), 6-11. https://doi.org/10.2527/af.2013-0027

Diskin, M. G., \& Kenny, D. A. (2014). Optimising reproductive performance of beef cows and replacement heifers. Animal, 8(s1), 27-39. https://doi.org/10.1017/S175173111400086X

Diskin, M. G., Mackey, D. R., Roche, J. F., \& Sreenan, J. M. (2003). Effects of nutrition and metabolic status on circulating hormones and ovarian follicle development in cattle. Animal Reproduction Science, 78, 345-370. https://doi.org/10.1016/s0378-4320(03)00099-X

Dixon, R. M., \& Stockdale, C. R. (1999). Associative effects between forages and grains: Consequences for feed utilization. Australian Journal of Agricultural Research, 50, 757-773. https://doi.org/10.1071/AR98165

Engelken, T. J. (2008). Developing replacement beef heifers. Theriogenology, 70, 569-572. https://doi.org/ 10.1016/j.theriogenology.2008.05.032

Forage and Grazing Terminology Committee. (1991). Terminology for grazing lands and grazing animals. Pocahontas Press, Inc. Blacksburg, VA.

Funston, R. N., Martin, J. L., Larson, D. M., \& Roberts, A. J. (2012). Nutritional aspects of developing replacement beef heifers. Journal of Animal Science, 90, 1166-1171. https://doi.org/10.2527/jas.2011-4569

Galyean, M. L., \& Goetsch, A. L. (1993). Utilization of forage fiber by ruminants. In H. G. Jung, D. R. Haltfield, \& J. Ralph (Eds.), Forage Cell Wall Structure and Digestibility (pp. 34-72). ASA-CSSA-SSSA, Madison, WI.

Ganskopp, D. A., Angell, R., \& Rose, J. (1993). Effect of low densities of senescent stems in crested wheat-grass on plant selection and utilization by beef cattle. Applied Animal Behavioral Science, 38, $227-233$. https://doi.org/10.1016/0168-1591(93)90021-G

Gasser, C. L. (2013). Joint Alpharma-Beef Species Symposium: Considerations on puberty in replacement beef heifers. Journal of Animal Science, 91, 1336-1340. https://doi.org/10.2527/jas.2012-6008

Grigsby, K. N., Kerley, M. S., Paterson, J. A., \& Weigel, J. C. (1993). Combinations of starch and digestible fiber in supplements for steers consuming low-quality bromegrass hay diet. Journal of Animal Science, 71, 1057-1064. https://doi.org/10.2527/1993.7141057x

Hafley, J. L. (1996). Comparison of Marshall and Surrey ryegrass for continuous and rotational grazing. Journal of Animal Science, 74, 2269-2275. https://doi.org/10.2527/1996.7492269x

Hodgson, J., Clark, D. A., \& Mitchell, R. J. (1994). Foraging behavior in grazing animals and its impact on plant communities. In G. C. Jr. Fahey (Ed.), Forage quality, evaluation, and utilization (pp. 796-827). Univ. of Nebraska, Lincoln.

Horn, G. W., \& McCollum, F. T. (1987). Energy supplementation of grazing ruminants. In M. B. Judkins, D. C. Clanton, M. K. Petersen, \& J. D. Wallace (Eds.), Proc. 1st Graz. Livest. Nutr. Conf., Jackson, WY (pp. 125-130).

Jarrige, R., Demarquilly, C., Dulphy, J. P., Hoden, A., Robelin, J., Béranger, C., Geay, Y., ... Petit, M. (1986). The INRA "Fill Unit" System for predicting the voluntary intake of forage-based diets in ruminants: a review. Journal of Animal Science, 63, 1737-1758. https://doi.org/10.2527/jas1986.6361737x

Kennedy, D. W., \& Bunting, L. D. (1992). Effects of starch on ruminal fermentation and detergent fibre digestion in lambs fed bermuda grass hay. Animal Feed Science and Technology, 36, 91-100. https://doi.org/ 10.1016/0377-8401(92)90089-O

Kunkle, W. E., Johns, J. T., Poore, M. H., \& Herd, D. B. (2000). Designing supplementation programs for beef cattle fed forage-based diets. Journal of Animal Science, 77, 1-11. https://doi.org/10.2527/jas2000.0021881 2007700ES0012x

Larson, R. L. (2007). Heifer Development: Reproduction and Nutrition. Veterinary Clinics of North America: Food Animal Practice, 23, 53-68. https://doi.org/10.1016/j.cvfa.2006.11.003

Lesmeister, J. L., Burfening, P. J., \& Blackwell, R. L. (1973). Date of first calving in beef cows and subsequent calf production. Journal of Animal Science, 36, 1-6. https://doi.org/10.2527/jas1973.3611

Mass, J. (1987). Relationship between nutrition and reproduction in beef cattle. Veterinary Clinics of North America: Food Animal Practice, 3, 633-646. https://doi.org/10.1016/s0749-0720(15)31135-X 
McDonnell, M. L., Klopfenstein, T. J., \& Merrill, J. K. (1982). Soybean hulls as energy source for ruminants. Nebraska Beef Cattle Rep. MP-43 (pp. 54-56). Univ. of Nebraska, Lincoln.

Meijs, J. A. C. (1986). Concentrate supplementation of grazing dairy cows. 2. Effect of concentrate composition on herbage intake and milk production. Grass and Forage Science, 41, 229-236. https://doi.org/10.1111/ j.1365-2494.1986.tb01808.x

Meijs, J. A. C., \& Hoekstra, J. A. (1984). Concentrate supplementation of grazing dairy cows. 1. Effects of concentrate intake and herbage allowance on herbage intake. Grass and Forage Science, 39, 59-66. https://doi.org/10.1111/j.1365-2494.1984.tb01665.x

Mott, J. J. (1985). Mosaic grazing-animal selectivity in tropical savannas of northern Australia. Proc. XV Intl. Grassl. Cong., Japan (pp. 1129-1130).

National Academies of Sciences, Engineering, and Medicine. (2016). Nutrient Requirements of Beef Cattle (8th ed.). Washington, DC: The National Academies Press.

Paterson, J. A., Belyea, R. L., Bowman, J. P., Kerley, M. S., \& Williams, J. E. (1994). The impact of forage quality and supplementation regimen on ruminant animal intake and performance. In G. C. Fahey, C. George, M. Collins, D. R. Mertens, R. David, \& L. E. Moser (Eds.), Forage Quality, Evaluation, and Utilization (p. 59). Am. Soc. Agron., Crop Sci. Soc. Am., Soil Sci. Soc. Am., Madison, WI.

Perry, G. A. (2012). Harnessing basic knowledge of factors controlling puberty to improve synchronization of estrus and fertility in heifers. Journal of Animal Science, 90, 1172-1182. https://doi.org/10.2527/jas. 2011-4572

Perry, R. C., Corah, L. R., Cochran, R. C., Brethour, J. R., Olson, K. C., \& Higgins, J. J. (1991). Effects of hay quality, breed, and ovarian development on onset of puberty and reproductive performance of beef heifers. Journal of Production Agriculture, 4, 13-18. https://doi.org/10.2134/jpa1991.0013

Pitt, R. E., Van Kessel, J. S., Fox, D. G., Pell, A. N., Barry, M. C., \& Van Soest, P. J. (1996). Prediction of ruminal volatile fatty acids and $\mathrm{pH}$ within the net carbohydrate and protein system. Journal of Animal Science, 74, 226-244. https://doi.org/10.2527/1996.741226x

Roberts, A. J., Nugent, III, R. A., Klindt, J., \& Jenkins, T. G. (1997). Circulating insulin-like growth factor I, insulin-like growth factor binding proteins, growth hormone, and resumption of estrus in postpartum cows subjected to dietary energy restriction. Journal of Animal Science, 75, 1909-1917. https://doi.org/10.2527/ 1997.7571909x

Russell, J. B., \& Wilson, D. B. (1996). Why are ruminal cellulolytics bacteria unable to digest cellulose at low pH? Journal of Dairy Science, 79, 1503-1509. https://doi.org/10.3168/jds.S0022-0302(96)76510-4

Sanderson, M. A., Rotz, C. A., Fultz, S. W., \& Rayburn, E. B. (2001). Estimating forage mass with a commercial capacitance meter, rising plate meter, and pasture ruler. Agronomy Journal, 93, 1281-1286. https://doi.org/ 10.2134/agronj2001.1281

Satter, L. D., Jung, H. G., van Vuuren, A. M., \& Engels, F. M. (1999). Challenges in the nutrition of high-producing ruminats. In H. G. Jung \& G. C. Jr. Fahey (Eds.), Proc. $5^{\text {th }}$ Int. Symp. on the Nutr. of Herbivores (pp. 609-646). ASAS. Savoy, Illinois, USA.

Scaglia, G. (2019). Stocking rate and energy supplementation effects on replacement beef heifers grazing annual ryegrass. Journal of Agricultural Science, 11(3), 1-13. https://doi.org/10.5539/jas.v11n3p1

Scaglia, G., \& Boland, H. T. (2014). Spatial arrangement of forages affects grazing behavior of beef heifers continuously stocked at low stocking rate. Crop Science, 54, 1227-1237. https://doi.org/10.2135/cropsci 2013.09.0622

Scaglia, G., Boland, H. T., \& Wyatt, W. E. (2009b). Effects of time supplementation on beef stocker calves grazing ryegrass. II. Grazing behavior and dry matter intake. Professional Animal Scientist, 25, 749-756. https://doi.org/10.15232/S1080-7446(15)30784-1

Scaglia, G., Gillespie, J. M., Boland, H. T., \& Wyatt, W. E. (2009a). Effects of time of supplementation on beef stocker calves grazing ryegrass. I. Performance and economic analysis. Professional Animal Scientist, 25, 737-748. https://doi.org/10.15232/S1080-7446(15)30783-X

Short, R. E., \& Bellows, R. A. (1971). Relationships among weight gains, age at puberty and reproductive performance in heifers. Journal of Animal Science, 32, 127-131. https://doi.org/10.2134/jas1971.321127x 
Stygar, A. H., Kristensen, A. R., \& Mukulska, J. (2014). Optimal management of replacement heifers in a beef herd: A model for simultaneous optimization of rearing and breeding decisions. Journal of Animal Science, 92, 3636-3649. https://doi.org/10.2527/jas.2010-7535

Van der Linden, Y., Van Gylswyk, N. O., \& Schwartz, H. M. (1984). Influence of supplementation of corn stover with corn grain on the fibrolytic bacteria in the rumen of sheep and their relation to the intake and digestion fiber. Journal of Animal Science, 59, 772-783. https://doi.org/10.2527/jas1984.593772x

Vendramini, J. M. B., Sollenberger, L. E., Dubeux, Jr., J. C. B., Interrante, S. M., Stewart, Jr., R. L., \& Arthington, J. D. (2006). Concentrate supplementation effects on forage characteristics and performance of early weaned calves grazing rye-ryegrass pastures. Crop Science, 46, 1595-1600. https://doi.org/10.2135/ cropsci2005.11-0419

Wettemann, R. P., \& Bossis, I. (2000). Nutritional regulation of ovarian function in beef cattle. Journal of Animal Science. Retrieved from http://www.asas.org/jas/symposia/proceedings/0934.pdf

Whittier, J. C., Lardy, G. P., \& Johnson, C. R. (2005). Pre-calving nutrition and management programs for two-year old beef cows. Professional Animal Scientist, 21, 145-150. https://doi.org/10.15232/S1080-7446 (15)31195-5

Willms, W. D., Dormaar, J. F., \& Schaalje, G. B. (1988). Stability of grazed patches on rough fescue grassland. Journal of Range Management, 41, 503-508. https://doi.org/10.2307/3899527

Wilm, H. G., Costello, O. F., \& Klipple, G. E. (1944). Estimating forage yield by the double sampling method. Journal of the American Society of Agronomy, 36, 194-203. https://doi.org/10.2134/agronj1944.00021962 $003600030003 x$

Zorrilla-Rios, J., Horn, G. W., Ford, M. J., McNew, R. W., \& Poling, K. B. (1985). In situ disappearance of dry matter and nitrogen of wheat forage, corn gluten meal, cottonseed meal and soybean meal in steers grazing wheat forage at two stages of maturity. Oklahoma Agric. Exp. Sta. Res. Rep. MP-117 (p. 169).

\section{Copyrights}

Copyright for this article is retained by the author(s), with first publication rights granted to the journal.

This is an open-access article distributed under the terms and conditions of the Creative Commons Attribution license (http://creativecommons.org/licenses/by/4.0/). 